
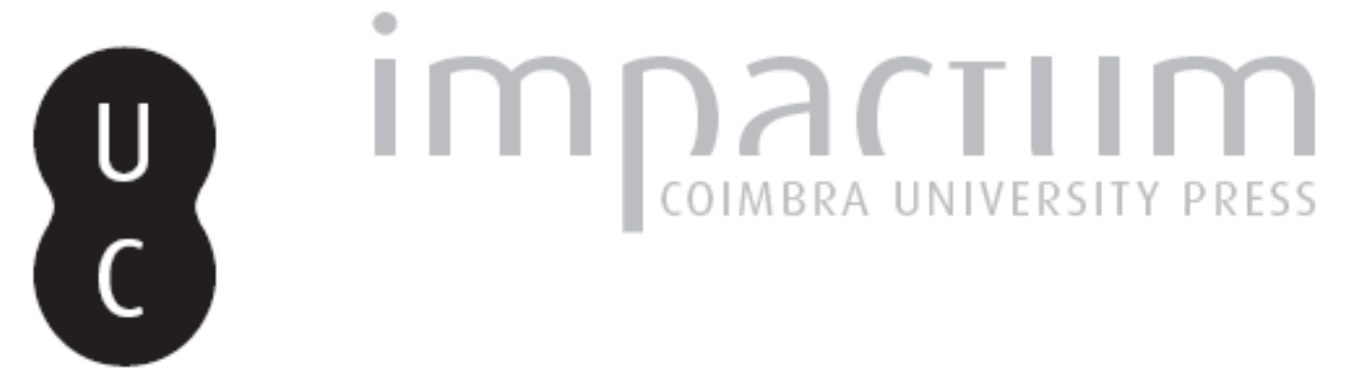

\title{
Direito do trabalho no Brasil: destruição ou transição de sua legislação
}

Autor(es): $\quad$ Campana, Priscila; Campana, Samya

Publicado por: Faculdade de Direito da Universidade de Coimbra

URL persistente:

URI:http://hdl.handle.net/10316.2/24735

DOI:

http://dx.doi.org/10.14195/0870-4260_52_7

Accessed : $\quad$ 26-Apr-2023 09:49:55

A navegação consulta e descarregamento dos títulos inseridos nas Bibliotecas Digitais UC Digitalis, UC Pombalina e UC Impactum, pressupõem a aceitação plena e sem reservas dos Termos e Condições de Uso destas Bibliotecas Digitais, disponíveis em https://digitalis.uc.pt/pt-pt/termos.

Conforme exposto nos referidos Termos e Condições de Uso, o descarregamento de títulos de acesso restrito requer uma licença válida de autorização devendo o utilizador aceder ao(s) documento(s) a partir de um endereço de IP da instituição detentora da supramencionada licença.

Ao utilizador é apenas permitido o descarregamento para uso pessoal, pelo que o emprego do(s) título(s) descarregado(s) para outro fim, designadamente comercial, carece de autorização do respetivo autor ou editor da obra.

Na medida em que todas as obras da UC Digitalis se encontram protegidas pelo Código do Direito de Autor e Direitos Conexos e demais legislação aplicável, toda a cópia, parcial ou total, deste documento, nos casos em que é legalmente admitida, deverá conter ou fazer-se acompanhar por este aviso.

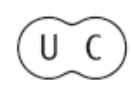




\section{UNIVERSIDADE DE COIMBRA \\ FACULDADE DE DIREITO}

BOLETIII DE CÊACCLS ECONÓNCACAS

VOLUME LII

$\begin{array}{llll}2 & 0 & 0 & 9\end{array}$

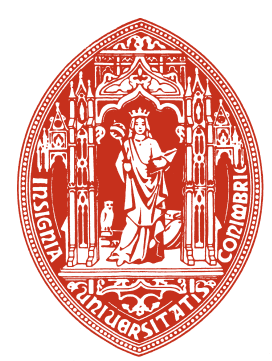

COIMBRA 


\section{Notas e Documentos}

DIREITO DO TRABALHO NO BRASIL:

DESTRUIÇÃO OU TRANSIÇÃO DE SUA LEGISLAÇÃO?

\section{Introdução}

O Direito do Trabalho vive uma crise crônica dada por uma ampla crise do capital, da qual uma abundante literatura apresenta um quadro clínico (CAPUto, 2000, 2001, Ceceña, 1995, Marini, 1979, 1996, Santos, 1987, 2000). Desde as críticas que mostraram sua outra face (MARX, 1996, PASUKANIs, 1989) até as críticas liberais que o atacam por sua falta de eficácia frente ao desemprego e à inovação tecnológica, a disciplina juslaboral é colocada à prova no contexto político e econômico atual. $\mathrm{Na}$ cultura de mercado, os direitos trabalhistas passam como uma idéia obsoleta.

Essa crise do Direito do Trabalho, ligada a uma transformação que ultrapassa o quadro institucional, toma múltiplas formas. Sua identidade simbólica, fortemente erigida no governo Vargas, como reino harmonioso entre "capital e trabalho", tem hoje descrédito tanto de capitalistas como de trabalhadores em relação à idéia de "justiça". As dificuldades de adaptação ontológica em relação às transformações da sociedade foram agravadas pelas políticas neoliberais, as quais acentuaram generalizadamente a precarização do trabalho, a marginalização da classe trabalhadora e o aumento das desigualdades sociais.

Quanto ao aspecto do Direito do Trabalho em si mesmo, esse se tornou mais complexo devido às transformações sociais e econômicas globais: da extinção progressiva da reprodução direta dos ofícios e trabalhadores ligados à grande indústria até ao peso, cada vez mais decisivo, do Setor de Serviços, passando por uma 
precarização generalizada das relações de trabalho (ANTUNES, 2002, 2005), assiste-se a um profundo questionamento das relações reais (e de ideário) de transmissão entre gerações a respeito dos "direitos trabalhistas".

Neste âmbito, entendemos que uma das principais transformações que afeta(ra)m os direitos trabalhistas nos últimos decênios - mas isso se encontra em outros campos sociais - é o domínio progressivo da dinâmica reformadora pelo ideário político e neoliberal.

Nossa proposta pretende refutar a oposição falaciosa entre "imobilistas"/"jurássicos" e "renovadores", como também evitar as teses alarmistas e catastróficas, às vezes necessárias, mas que desmobilizam quando parecem significar que, estando morto o "tradicional celetista" direito do trabalho, "tudo está perdido". O Direito do Trabalho é complexo, pois na medida em que como outras esferas da sociedade burguesa - inclui o sentido da vida individual e coletiva (em que liga o passado e o futuro e mistura gerações e diferentes formas de os homens produzirem suas vidas), também é um campo de forças, um afrontamento e luta contínua de representações e lógicas diferentes (as quais não são nem essências nem fatalidades).

A questão fundante que investigamos nesse artigo é sobre o conteúdo e a dinâmica do "modelo" de Direito do Trabalho que se impõe atualmente. As transformações em curso representam uma melhor adaptação do Direito do Trabalho à economia capitalista no contexto do neoliberalismo (o que significa maior perigo à autonomia desse direito), ou representam a extinção/destruição do Direito do Trabalho como tal, num contexto em que o trabalho - enquanto (relação ontológica e) modo de reprodução da existência humana - vem sendo duramente afectado pela reprodução do capital?

Partimos de duas hipóteses em nossa investigação. A primeira delas é que em função da tendência de diminuição da intervenção estatal nos vários setores sociais e econômicos do país, assinalada também pela "globalização", o Estado afasta-se de suas funções jurisdicionais até o ponto em que as normas jurídicas passem a ser consideradas empecilho para o livre desenvolvimento 
do mercado. Portanto, a desregulamentação faz parte do atual contexto que abrange o Estado enfraquecido como poder instrumentalizador do Direito do Trabalho. Passa-se então da flexibilidade de direitos à desregulamentação de direitos por conveniência política e econômica. A segunda hipótese é a de que a globalização econômica impele os Estados soberanos à desregulamentação do Direito do Trabalho, tendo em vista uma pretensa modernização que os levaria a competir com maiores vantagens no mercado mundial.

A sociedade atual, marcada por avanços tecnológicos e mudanças no sistema produtivo, é qualificada como complexa e tem sua influência direta sobre o Estado e o Direito. É propagado que estes devem, no contexto de globalização, "acompanhar" os progressos da modernidade, segundo visão atual do neoliberalismo.

Não ocorrendo isto, o modelo adotado atualmente para regular as relações de trabalho, a exemplo do Brasil, é chamado de anacrônico face às transformações no sistema produtivo capitalista mundial, sendo caracterizado como rígido.

Cabem então, neste contexto, os discursos da flexibilidade e da desregulamentação do Direito do Trabalho. Há preocupação quanto à desregulamentação juslaborista no Brasil, na medida em que essa se traduz na alteração prejudicial de grande parte de normas positivadas protetoras do hipossuficiente.

Sendo parte de um todo ligado a uma visão macro-econômica, a serviço dos interesses do grande capital, o processo desregulamentador não traz benefícios para os trabalhadores, mas simboliza apenas forma de maior espoliação do trabalho em proveito da maior concentração de renda e do aprofundamento da crise econômica nos países de Terceiro Mundo (Passos, 1996).

\section{Flexibilização e desregulamentação}

Muitos autores diferenciam o conceito de flexibilização e o de desregulamentação, traçando critérios comparativos e elaborando classificações. 
Para SüsseKIND (1997, p. 61), por exemplo, a desregulamentação do Direito do Trabalho não se confunde com a flexibilização das relações de trabalho, explicando que:

A flexibilização corresponde a uma fenda no princípio da inderrogabilidade das normas de ordem pública e no da inalterabilidade "in pejus" das condições contratuais ajustadas em favor do trabalhador, visando facilitar a implementação de nova tecnologia ou preservar a saúde da empresa e a manutenção de empregos. Na flexibilização sobrevive a legislação de proteção do trabalho com algumas normas gerais irrenunciáveis e outras que admitem as adaptações precitadas; na desregulamentação o Estado não intervém nas relações de trabalho, para que a autonomia privada, coletiva ou individual, disponha sem limitações legais, sobre as condições de trabalho. Seria o retorno à fase histórica em que as péssimas condições de trabalho justificaram a ampla e diversificada reação que fundamenta o advento da legislação social-trabalhista.

Num outro ponto de vista, NASCimento (2003) entende que o vocábulo flexibilização refere-se ao direito individual do trabalho, enquanto desregulamentação diria respeito ao direito coletivo. Desta forma, "flexibiliza-se o direito individual e desregulamenta-se o direito coletivo.

Para Siqueira Neto (1995, p. 48), a desregulamentação dos direitos trabalhistas "é o processo pelo qual os mesmos são derrogados, perdendo a regulamentação. A desregulamentação, na verdade, é um tipo de flexibilização promovida pela legislação". Segundo ele, "a flexibilização do direito do trabalho consubstancia-se no conjunto de medidas destinadas a afrouxar, adaptar ou eliminar direitos trabalhistas de acordo com a realidade econômica".

Entretanto, há também o entendimento de que a flexibilização é espécie do gênero - processo - de desregulamentação. Flexibilização, assim, pode ser definida como a possibilidade, inserida na própria lei existente, de excetuar alguns direitos trabalhistas, tornando-os maleáveis. Segundo Maccalóz (1997) "por essa via não havia a determinação de extinguir a legislação, 
ela permaneceria aí como uma sugestão às partes, ou mesmo de caráter impositivo nas condições previamente estabelecidas". ${ }^{1}$

Num conceito simples, flexibilizar significaria dar maleabilidade à legislação do trabalho, mesmo que paulatinamente. De igual modo, pode-se dizer que a flexibilização do direito laboral "tem uma característica própria e inconfundível, que é a possibilidade de alteração da relação contratual entre empregado e empregador, com o objetivo de dar uma plasticidade às regras obreiras, tirando-lhes os aspectos "tradicionais"” (PEREIRA, 1995, p. 66).

Assim, existe a possibilidade de tentar diferenciações entre os vocábulos "flexibilização" e "desregulamentação". Do mesmo modo, é possível uma esquematização dos tipos de flexibilização em setores na relação de trabalho. ${ }^{2}$ Entretanto, como o objetivo deste trabalho não está centrado nestas diferenciações classificatórias, "flexibilização" ou "desregulamentação" são aqui empregadas como sinônimos. Ou seja, ambos os institutos representam um atraso histórico do direito trabalhista brasileiro, indo de encontro aos princípios da proibição de retrocesso social e da proteção ao trabalhador, protegidos constitucionalmente.

Para Carvalho (1993, p. 99), "o que se pretende é o enfraquecimento das normas que resumam conquistas dos trabalhadores, facilitando, assim, a maior liberdade daquele que está do lado oposto do balcão: o empregador".

${ }^{1}$ A autora explica: "assim ocorre na Espanha, que adotou uma regulamentação mínima para todos os contratos trabalhistas não compreendidos nas negociações coletivas. Isto significa, nesta maleabilidade, a eliminação aos poucos da legislação trabalhista pois seu caráter tutelar e protecionista orienta na indisponibilidade do seu conteúdo normativo" (p. 10).

${ }^{2}$ Como, por exemplo, o da mobilidade do trabalhador, o da duração do contrato individual de trabalho e o setor salarial. Quanto à mobilidade, ocorre flexibilização referente à movimentação do empregado para dentro ou fora da empresa, significando a liberdade do empregador em admitir e despedir conforme sua vontade. Quanto à duração do contrato individual de trabalho, significa que, em função das necessidades das empresas, passam a existir contratações de trabalhadores temporários, contratos por prazo determinado, facilitando a rotatividade da mão-de-obra. E quanto ao salário, não somente teria seu valor reduzido como também estaria generalizada a remuneração maleável do trabalho prestado (Pereira, 1995). 
O discurso neoliberal de globalização defende a desregulamentação como necessária para atender a uma crise provisória do capital, afirmando que gerará empregos. Contudo, esclarece Pereira (1995, p. 67): “o que se constata é uma forma de obrigar os trabalhadores a cederem seus direitos laborais como meio de enfrentar a crise econômica, admitindo a incorporação de certas formas contratuais atípicas".

Desta maneira a flexibilização veste-se de simples reformatio in pejus, modificando as leis trabalhistas existentes para reduzir materialmente direitos, como uma estratégia econômica casuísta.

É relevante observar a herança do discurso neoliberal de flexibilizações das normas fundamentais do trabalhador e perceber a atualidade da nova ordem internacional de globalização e os projetos econômicos "criados" para os países periféricos. Assim, é possível compreender o processo desregulamentador, em que há "uma inversão de valores, em que o Direito do Trabalho perde sua expressão de humanismo jurídico (a serviço de um valor absoluto e universal, que é a dignidade do ser humano que trabalha) para valores meramente econômicos" (MACCALóz, 1997)³.

\section{As flexibilizações nas leis trabalhistas}

O caráter tuitivo das leis trabalhistas estabelece normas com limites mínimos; fora destes, há possibilidade de negociação, havendo flexibilização. É o que enuncia o artigo 444 da Consolidação das Leis do Trabalho (CLT): "as relações contratuais de trabalho podem ser objeto de livre estipulação das partes interessadas em tudo quanto não contravenha às disposições de proteção ao trabalho, aos contratos coletivos que lhes sejam aplicáveis e às decisões das autoridades competentes".

3 "É na desmontagem das tradicionais relações de trabalho que entra a flexibilização como parte dessa grande estratégia de globalização, ou melhor, livre circulação de capitais e riquezas sem obstáculos que lhe venham a diminuir a importância. Do ponto de vista capitalista, ela é apresentada como uma reação à rigidez (...) na aplicabilidade das normas legais de proteção ao trabalho, no Brasil" (Maccaloz, 1997, p. 68). 
São institutos históricos jurídicos da flexibilização a lei n. ${ }^{\circ}$ 5107/66 do FGTS (Fundo de Garantia do Tempo de Serviço), os incisos VI, XIII e XIV do art. $7 .^{\circ}$ da Constituição Federal de 1988 e, na década de noventa, o projeto de lei que instituiu o contrato de trabalho por tempo determinado. Além destes, inúmeros projetos de lei tramitam no Congresso Nacional com este escopo, como em 2001, no projeto que visava instituir que as decisões em negociação coletiva prevalecessem sobre a legislação trabalhista ${ }^{4}$.

Na década de 1960, a mais profunda flexibilização ocorreu com o instituto do FGTS, criado pela Lei n. ${ }^{\circ}$ 5107, de 13.09.1966, paralelamente aos Capítulos V e VII do Título IV da CLT, uma opção de responsabilidade do trabalhador, o qual se beneficiaria com a patrimonização da antiga estabilidade ${ }^{5}$.

Com o novo instituto, acabou o reconhecimento de qualquer estabilidade, reduzindo os custos imediatos da demissão de trabalhadores. Os empregadores poderiam agora demitir empregados com dez anos de casa sem justa causa. Da mesma forma, foi alterado o modo de pagamento das indenizações, eliminando-se

${ }^{4}$ Sobre este tema Arnaldo SüsseKind (1997, p. 50) pondera: "é surpreendente e até estranho, por isso mesmo, que o Presidente Fernando Henrique Cardoso, a pretexto de flexibilizar a aplicação da legislação trabalhista, tenha se empenhado, com incompreensível e obstinada insistência, no sentido de ser aprovado o Projeto de Lei do Executivo n. 5483/01, que visa a complementar o art. 618 da CLT para permitir que convenções e acordos coletivos prevaleçam, salvo em excepcionais hipóteses, sobre a lei ordinária”.

${ }^{5}$ Segundo as leis trabalhistas anteriores a 1966, os trabalhadores com permanência entre um e dez anos na mesma empresa tinham direito a indenização quando demitidos sem justa causa. A indenização equivalia a um mês de salário para cada ano de trabalho na empresa. Além disso, os trabalhadores com mais de um ano de emprego tinham direito a aviso prévio de trinta dias e a pagamento extra de soma equivalente a um mês de salário. A quantidade das somas envolvidas desincentivava as demissões em massa nas empresas. Os trabalhadores empregados há mais de dez anos, na mesma empresa, adquiriam "estabilidade", somente podendo ser demitidos se o empregador provasse falta grave em processo judiciário. Se o empregador fosse sucumbente ao tentar demitir um trabalhador estável, era obrigado a readmiti-lo pagando-lhe os salários atrasados. Com a concordância do empregado, o empregador poderia deixar de readmiti-lo, pagando-lhe o dobro da indenização. 
a necessidade de o empregador gastar grandes somas de uma vez em caso de demissões ou fechamento das empresas. Além disso, possibilitou aos empregadores liberdade para aumentar a rotatividade da mão-de-obra, mantendo mais baixos os salários. Assim, o FGTS substitui a antiga estabilidade do empregado, desonerando o empregador de pagamento de indenização ao demitido imotivadamente.

A Constituição Federal de 1988 já não alude à estabilidade do empregado, apenas inseriu, entre os direitos sociais, no art. 7.', o item III, "fundo de garantia do tempo de serviço".

Ainda no plano infraconstitucional, há a antiga lei que previa a redução de jornada e de salários sob as condições ali previstas (Lei n. ${ }^{\circ}$ 4923/65).

Digna de apreciação é a inspiração flexibilizadora constante do ordenamento jurídico constitucional: o art. $7 .^{\circ}$, VI (quanto à irredutibilidade salarial, salvo o disposto em convenção ou acordo coletivo), XII (quanto à compensação e redução de jornada, mediante acordo ou convenção coletiva), XIV (jornada de seis horas para o trabalho realizado em turnos ininterruptos de revezamento, salvo negociação coletiva). A redução salarial já era prevista no art. 503 da CLT, no caso de "força maior ou prejuízos devidamente comprovados".

Uma terceira forma que compõe o arcabouço de possibilidades flexibilizadoras são as terceirizações. Estas acabam com a sinalagmaticidade perfeita do contrato laboral, objetivando provocar um desvio do eixo fundamental do conflito, que deixa de vincular o trabalhador com o capitalista. Conseqüência disso é também a desmobilização da classe trabalhadora na luta por seus direitos. Os seus adeptos defendem-na com base na eficiência de produção e crise do emprego ${ }^{6}$.

${ }^{6}$ Eficiência porque, assim, a atividade capitalista poderia ser concentrada na atividade-fim, desligando-se das atividades-meio. E como fato incentivador de postos de trabalho porque, reduzindo os custos da produção para o empresário terceirizado, maior número de vagas seriam abertas juntos aos empreendedores terceirizantes. 
São falaciosos estes argumentos, haja vista que o problema do desemprego é estrutural e que as medidas servem tão somente para atender aos interesses dos empresários em busca de maior lucratividade e descomprometidos com a realidade social de desigualdade econômica, pobreza, analfabetismo do Brasil.

De maneira idêntica, a Lei n. ${ }^{\circ}$ 9601/98, que instituiu o contrato temporário de trabalho (e o banco de horas), significou mais um golpe neoliberal contra a classe trabalhadora brasileira, contribuindo para a redução salarial e para a desmobilização dos trabalhadores, pois trata-se de recurso fácil aos empregadores na rotatividade de mão-de-obra temporária.

O FGTS já havia sido criado, substituindo a estabilidade no emprego. Agora, com o contrato por tempo determinado, o percentual de recolhimento deste Fundo cai de $8 \%$ para $2 \%$, não sobrando nem uma coisa nem outra. Também é extinta a obrigação de pagamento de aviso prévio, a multa de $40 \%$ sobre o FGTS e a estabilidade provisória em virtude de gravidez e de exercício de mandato sindical. As horas extras exigidas do trabalhador poderão ser compensadas em prazo de até um ano (CAMPOS, 1997).

O argumento principal dos ideólogos das desregulamentações e mais precisamente deste projeto é a geração de empregos, já que, segundo eles, as empresas pagam muitos encargos sociais. Como escreve, ironicamente, Campos (1997), "é de dar pena a situação do empresariado", explicando em seguida:

as margens de lucro das empresas brasileiras são elevadíssimas. (...) Qual a contrapartida para os trabalhadores que, em última instância, geram essa prosperidade para as classes dominantes? Em uma sociedade desigual como a nossa, o discurso, a capacidade de perverter o sentido de uma narrativa revela-se, de fato, uma das mais elaboradas habilidades do homem. As ideologias conseguem, por exemplo, convencer a opinião pública de que o trabalhador é o responsável pela situação de atraso social em que vive o país. (...) Apesar de receber o menor salário mínimo do mundo, o trabalhador brasileiro ainda é culpado pela crise em que vivemos. Usa-se, agora, essa argumentação para justificar a 
precarização das relações de trabalho, retirando direitos que fazem parte do patrimônio dos trabalhadores brasileiros. Cabe lembrar que em países que desregulamentaram o mercado de trabalho, como Argentina e Espanha, as taxas de desemprego estão atualmente entre as mais elevadas - respectivamente, $29 \%$ e $24 \%$.

Ou seja, o discurso da rigidez da CLT é falacioso; primeiro, pelas inúmeras possibilidades de flexibilização atualmente implementadas nas relações de trabalho e, segundo, pelas constantes desregulamentações que sofreram as normas celetistas, ainda antes do advento da Constituição Federal de 1988.

O direito do trabalho sempre foi flexível. Mas, com as políticas econômicas atuais, houve maior desregulamentação e precarização nas relações trabalhistas. Não há razão, portanto, para se propagar a idéia de extinção da CLT com fundamento em sua pretensa rigidez. O objetivo estaria respaldado no desejo de justificar a idéia equivocada de que este corpo de leis é um "entulho" originado na ditadura de Getúlio Vargas.

\section{O ideário da rigidez das leis trabalhistas e a "neces- sidade" de flexibilização diante das crises capitalistas}

Uma das grandes falácias propagadas atualmente, principalmente por causa das crises estruturais do capitalismo, e que justificariam a necessidade de se alterar totalmente a CLT brasileira, pois que seria um entrave ao desenvolvimento econômico do país, é o de que possui extrema rigidez, impedindo a negociação entre empregados e empregadores. ${ }^{7}$

7 A crise da economia, as novas tecnologias e o desemprego crescente, bem como a competitividade internacional, justificariam a flexibilização. O economista José Pastore já opinava em 1994 que a Constituição, a CLT e a Justiça do Trabalho "obrigam as partes a se acomodarem a um sistema ultrapassado que se baseia muito mais na legislação do que na negociação (...) numa quadra em que o mundo se encolhe, a economia se globaliza e tudo é feito com 
Antes mesmo da Constituição Federal de 1988 e da CLT, a legislação trabalhista já havia curvado-se diante das políticas econômicas de seus governantes. Em 1942, sob a ditadura varguista, vários direitos trabalhistas foram maleabilizados diante das necessidades da economia de guerra, como a jornada de trabalho, as horas extras, o trabalho noturno e o direito de férias. Explica Lenharo (1986, p. 28):

os objetivos "nacionais" de uma economia de guerra que levaram o governo, em 1942, a aumentar novamente a jornada de trabalho para 10 horas, o que batia com as aspirações dos empresários ainda não conformados com a sua regulamentação. Horas extras, trabalho noturno das mulheres também passavam a receber um tratamento mais flexível, atendendo-se à necessidade 'nacional' de se exportar mais, principalmente têxteis, em condições favoráveis no mercado internacional. Ainda em 42, o direito de férias foi sustado nas indústrias consideradas militarmente essenciais, entre as quais as têxteis.

Quer dizer, a prática de flexibilização das normas trabalhistas não é fenômeno tão atual quanto parece ser. Infelizmente, como na situação de economia de guerra supracitada, a legislação foi colocada de lado quando erigida a "produtividade nacional" como primeiro valor.

Entretanto, a expressão flexibilização começou a ser utilizado como "necessidade" no Brasil antes mesmo do Consenso de Washington, em 1989. As leis sociais deveriam ser flexibilizadas porque eram "desatualizadas": impediam a concorrência dos produtos brasileiros no mercado mundial, oneravam o empresariado nacional, geravam desemprego, bloqueavam o desenvolvi-

uma velocidade alucinante que exige mecanismos de ajustamento rápido do lado dos agentes econômicos" (PASTORE, 1994). Quase mais de uma década depois, o mesmo economista persiste: "por força da rigidez da nossa legislação trabalhista, as medidas nos campos do emprego e salário são dolorosas e conflitivas. A CLT deixa muito pouco espaço para as partes serem cordatas e fazerem adaptações” (PASTORe, 2001). 
mento econômico, violavam a liberdade das partes no contrato de trabalho, afastavam a livre negociação; enfim, a legislação social passou a ser o problema "causador de todos os males". Procurando modificá-la, retirá-la, flexibilizá-la, a modernidade chegaria ao país e seria possível tornar o Brasil um país de Primeiro Mundo.

Nessa década de 2000, especialmente nos anos 2007/2008, com o aumento do número de desempregados na Europa, debate-se a chamada "flexissegurança", conforme Dallegrave (2008, p. 52):

mais uma medida em sintonia com a ideologia neoliberal, uma vez que os objetivos são claros: facilitar a vida da iniciativa privada em detrimento das condições de trabalho que se tornarão mais precárias em face da política de flexibilidade em seus diversos aspectos: contratação temporária; dispensa sem ônus; modalidades de salário vinculadas ao resultado; fixação de horários flexíveis visando atender exclusivamente a demanda da produção.

A flexibilização dos direitos sociais, assim, tornou-se mais um mecanismo capitalista de manutenção do sistema de exploração e auferição de lucros pelas empresas e conglomerados econômicos, mormente em momentos de crises.

Entretanto, como pondera Souto Maior (2009):

a superação de uma crise econômica estrutural requer sacrifícios de cima para baixo e não de baixo para cima. Não se promove uma sociedade, salvando empresas e deixando pessoas à beira da fome. Se há um problema na conjuntura econômica, que atinge a todos indistintamente, e não apenas a uma ou outra empresa, é necessário, então, o sacrifício conjunto, começando pelos próprios empresários e passando por diversos outros setores da sociedade (profissionais liberais, servidores públicos, senadores, deputados, prefeitos, governadores, juízes, etc.). É impensável que se busque a solução de problemas econômicos estruturais do país com o sacrificio apenas de trabalhadores cujo salário já está entre os mais baixos do mundo. Não é possível que as pessoas sérias 
desse país acreditem que o $13^{\circ}$. salário de um trabalhador, já "terceirizado", que ganha pouco mais de $\mathrm{R} \$ 400,00$ por mês constitua entrave ao desenvolvimento econômico.

E, ao contrário do que se apregoa ideologicamente, o desemprego ou as crises econômicas não se resolvem com as práticas desregulamentadoras. Assim, diante das medidas flexibilizadoras adoptadas entre 1998 e 2001, os índices deveriam ter queda, mas, não foi o que aconteceu (Dallegrave, 2008). ${ }^{8}$

\section{Destruição ou transição das leis trabalhistas? Conside- rações finais}

Entende-se que o capital é o momento histórico em que o produto do trabalho do homem (esse trabalho materializado, objetivado), separa-se dele, aliena-se do mesmo, se volta contra o próprio homem dominando-o e escravizando-o, mas não para fazer dele uma força - tão somente - submissa, mas uma força submissa com um objetivo precípuo, qual seja, que o homem é escravo do produto do seu trabalho porque se transforma em matéria-prima para: primeiro, manter a riqueza no nível em que ela existe, no padrão em que ela iniciou o ciclo; segundo, ampliar esta riqueza, ou seja, produzir mais riqueza do que a antecipada. ${ }^{9}$

${ }^{8}$ Conforme índices do DiEese e BACEN, em 12/97, registrou-se 4,5\% da PEA, período que iniciou a Reforma Trabalhista do Governo FHC. Em 12/99 subiu para 6,7\%. Em 12/02 subiu novamente para 10,5\%, quando findou a "reforma trabalhista". Em 12/03 e 12/04 a taxa de desemprego fechou próxima da casa dos $10 \%$. Somente a partir de $12 / 05$ a taxa de desemprego começou a cair, alcançando a sua menor taxa em 12/07, na casa dos 7,4\%.

${ }^{9}$ Isso porque a acumulação de capital repousa sobre determinadas "leis", proporções/relações entre variáveis fundamentais de seu movimento: Composição Orgânica do Capital - COC -, ou seja, e de forma resumida, COC = CC/CV; Taxa de Mais-Valia, ou seja, Tx. MS = MV (mais-valia)/CV (capital variável) e Taxa de Lucro, ou seja, Tx L = MV/ CC (capital constante) + CV, podendo, ainda, a Tx L ser escrita: TX $=$ Tx MV/ COC +1 (MARX, 1996). 
O desenvolvimento dessa relação específica entre os trabalhadores e a sua riqueza, a qual reproduz a propriedade privada capitalista e, ao mesmo tempo, a não-propriedade privada dos próprios trabalhadores e que tende a produzir riqueza e as forças produtivas ampliadamente, é, não obstante, contraditória: ao mesmo tempo que o processo produtivo sob sua égide expulsa os homens da produção, o capital (a relação social) quer homens na produção. Assim, o desenvolvimento de novas tecnologias (SAntos, 1987) "flexíveis" (com a conseqüente precarização que encerra), consonantes com uma nova forma "laboratorial" de (re)produção do capital (CAMPANA, S., 2006), e a permanência da individualização da relação trabalhista entre empregadores e empregados (isto é, o fato de o trabalhador ser o proprietário privado de sua força de trabalho e de o capitalista dispor dessa força individualmente, por mais socializada que vá se construindo a vida), apontariam um declínio do Direito do Trabalho em prejuízo dos trabalhadores, já que o que estaria em jogo seria o próprio "direito ao trabalho", ainda presente como única forma de os homens reproduzirem suas vidas, mesmo que precarizadamente.

Nesse contexto de dificuldades para o homem se fazer "no" e "pelo" trabalho (como um direito ao trabalho) evidencia-se a perda de direitos trabalhistas. Desse modo, o universo do trabalho (e sua matiz, "direito ao trabalho") - como forma ontológica e o dos direitos trabalhistas parecem se confundir a ponto de dominantemente não se ver mais a importância de ser da autonomia do Direito do Trabalho nem o significado político de sua separação em relação aos desígnios da economia de livre mercado. Vive-se, pois, uma época de enfraquecimento dos direitos trabalhistas que no passado foram fundamentais para a construção e garantia do modo de vida dos homens assentado sobre o trabalho e inclusive no capital.

Não obstante, interroga-se sobre os limites dessa "evolução" do direito trabalhista em função de suas próprias conseqüências. O Direito do Trabalho é um universo que, ao mesmo tempo que avança, traz contradições dialéticas. A lógica do modelo de flexibilização e desregulamentação do Direito do Trabalho é uma lógica autodestrutiva para o próprio sistema na medida em que 
fragiliza a relação homem-mundo, pois esta se assenta sobre o trabalho, o qual vem sendo solapado pelo próprio desenvolver-se do modo de produção capitalista. Deste modo, se essa evolução responde bem a certas tendências (na verdade, pode ser ela mesma uma contra-tendência da crise) do capital, a perda (irreversível) de direitos do trabalho não é algo ilusório, considerando os imperativos da economia capitalista? Conseqüentemente, se ainda não estamos na liquidação total dos direitos trabalhistas, então assistimos a uma transição do Direito do Trabalho, em face do desmantelamento do elo ontológico homem-trabalho?

Há dois grandes tipos de contradições que aparecem: uma que toca à cultura e aos valores que o Direito do Trabalho subentende e outra que se poderia dizer propriamente econômica. Querer tornar o Direito do Trabalho em prol de organizações mais eficazes e de "mais empregos" (mesmo que flexibilizando-o) supõe que se aceite - minimamente - a necessidade e importância dos direitos trabalhistas, de sua regulamentação, mas não deve-se confundi-los como algo inútil. Se os direitos trabalhistas são visto como inúteis, onerosos, então, a lógica do "capital e trabalho" que justifica a expansão dessa relação e da idéia de que o "trabalho dignifica" não tem mais sentido algum. Quem vai pagar pela "economia dos direitos trabalhistas"?

Em nível mais profundo, a lógica do modo de produção capitalista é autodestrutiva, mas o tom catastrófico de certos panfletos que declaram que o Direito do Trabalho já é "ruim para o trabalhador", ou que já é em si capitalista, não ajuda a estabelecer uma constatação precisa da situação atual. É falso dizer que o discurso dominante capitalista apropriou-se de tudo e que o Direito do Trabalho está inteiramente a serviço da ordem capitalista. Basta considerar o estado das relações de forças e examinar as lutas internas ao próprio Direito do Trabalho para constatar que certas "reformas" ainda não foram efetivadas. A flexibilização e desregulamentação a favor da competitividade e do mercado ainda não são aceitas facilmente por todos. De modo que essa resistência é um dos maiores obstáculos à sua expansão.

A onda de "mudança" no Direito do Trabalho deve ser compreendida na longa duração e como produto de uma acentuação 
do desenvolvimento do modo de produção capitalista. E, em última instância, essa onda acentua a crise do vínculo humano com o trabalho. São, portanto, os preceitos e práticas do neoliberalismo que é preciso combater e são também os fundamentos dessa forma de sociedade que é preciso interrogar, já que se mostram esgotadas. 


\section{REFERÊNCIAS BIBLIOGRÁFICAS}

Antunes, Ricardo. O sentidos do trabalho. São Paulo: Boitempo, 2002. O caracol e sua concha: ensaios sobre a nova morfologia do trabalho. São Paulo: Boitempo, 2005.

Construção e desconstrução do trabalho no Brasil. In ANTUNES, Ricardo (org). Riqueza e miséria do trabalho no Brasil. São Paulo: Boitempo, 2006.

Campana, Priscila. Direito Trabalhista a Contrapelo: desconstruindo discursos e práticas de poder. 233 f. 2004. Tese (Doutorado em Direito) Programa de Pós-graduação em Direito - Universidade Federal do Paraná, Curitiba, 2004.

CAmpana, Samya. A emancipação humana a partir da síntese histórica do desenvolvimento das forças produtivas sociais: o sistema de laboratório. 2006. 256f. Dissertação (Mestrado em Economia) - Programa de Pós-Graduação em Economia, Universidade Federal de Santa Catarina, Florianópolis, 2006.

CAmpos, Lauro. Neoliberalismo e contrato temporário de trabalho. Opinião Econômica. Folha de S.Paulo. 15/01/97.

CAPUto, Orlando. La globalización de la economía mundial desde la crisis asiática. Aportes-Revista de la Facultad de Economía de la BUAP. Puebla, ano 5, n. 13, p. 31-53, abr. 2000.

. Las crisis del capitalismo global. In: Caputo, O.; Estay, J.;

Villa, J. Capital sin fronteras: polarización, crisis y Estado-nación en el capitalismo global. Barcelona: Icaria, 2001.

Carvalho, Amílton Bueno de. Flexibilização e direito alternativo. In: Souza Jr, José Geraldo de. Introdução crítica ao direito do trabalho. Brasília: Universidade de Brasília, 1993.

CeCeñA, A. E. (coord.). La internacionalización del capital y sus fronteras tecnológicas. México D.F.: El Caballito, 1995-a.

Coutinho, Aldacy Rachid. Globalização e direito do trabalho. Direito e Democracia (ULBRA), Porto Alegre, v. 1, n. 1, p. 163-176, 2000.

Delgado, Maurício Godinho. Curso de direito do trabalho. São Paulo: LTr, 2008. 
Dallegrave Neto, José Affonso. Flexissegurança nas relações de trabalho. Que bicho é esse? Revista Trabalhista (Rio de Janeiro), v. 25, p. 49-53, 2008.

Faria, José Eduardo (org). Direito e globalização econômica. São Paulo: Malheiros, 1996.

Hobsbawn, Eric. Globalização, democracia e terrorismo. São Paulo: Companhia das Letras, 2007.

Lenharo, Alcir. Sacralização da política. São Paulo: Papirus, 1986.

MacCALóz, Salete. Globalização e flexibilização. In: Globalização, neoliberalismo e direitos sociais. Rio de Janeiro: Destaque, 1997.

Marini, Ruy Mauro. Plusvalía extraordinaria y acumulación de capital. Cuadernos Políticos, México D.F., n. 20, 1979.

. Procesos y tendencias de la globalización capitalista. In: MarinI, R. M.; Millán, M. (Coord.). La teoría social latinoamericana: tomo IV, cuestiones contemporáneas. México D.F: UNAM, 1996. p. 49-68.

Marx, Karl. O Capital: o processo de produção do capital. Livro I, v.1 e v.2, 15 a ed. - Rio de Janeiro: Bertrand Brasil, 1996.

Nascimento, Amauri Mascaro. Flexibilização do direito do trabalho: dimensão e experiência brasileira. Revista Forense, v. 99, p. 31-38, set./out. 2003.

Passos, Edésio. O princípio da proteção e a desregulamentação das relações de trabalho. Revista Genesis, Curitiba, p. 20-24, jul. 1996.

Pastore, José. Encargos sociais. Folha de S. Paulo, Opinião Econômica, 05.07.1994.

Pastore, José. Racionamento, emprego e salário. O Estado de S. Paulo, 22.05.2001.

Pasukanis, Evgeny B., A teoria geral do direito e o marxismo, Rio de Janeiro, Renovar, 1989.

Pereira, Josecleto Costa de Almeida. A problemática da flexibilização do direito do trabalho no Brasil. Jurisprudência Catarinense $n^{\circ} 70$. p. 66.

SAder, Emir (org.). Pós-neoliberalismo: as políticas sociais e o Estado democrático. São Paulo: Paz e Terra, 1996.

Santos, Theotônio dos. Revolução científico-técnica e acumulação de capital. Petrópolis: Vozes, 1987.

A teoria da dependência: balanço e perspectivas. Rio de Janeiro: Civilização Brasileira, 2000.

Siqueira Neto, José Francisco. Desregulamentação ou Regulamentação?. Trabalho e Processo [s.1.:sn.], n. 7, dezembro de 1995. 
Souto Maior, Jorge Luiz. Contra oportunismos e em defesa do direito social.

[Inédito] São Paulo, 22 de janeiro de 2009. Disponível em www.amatra4.jus.br.

Sussekind, Arnaldo. A globalização da economia e o direito do trabalho. Revista LTr. [s.n. s.1], n. 1, janeiro de 1997.

Priscila Campana

Doutora em Direito/Universidade Federal do Paraná/Brasil Professora na Universidade Regional de Blumenau/SC

Samya Campana

Mestra em Economia/Universidade Federal de Santa Catarina/Brasil Pesquisadora/Bolsista da CAPES 